\title{
The Use of Offer and Acceptance and their Commissive Implication in the Sulha Tribunal
}

\author{
Ali Odeh Hammoud Alidmat ${ }^{1} \&$ Mohamed Ayed Ayassrah ${ }^{1}$ \\ ${ }^{1}$ Aqaba University College, Al-Balqa Applied University, Jordan \\ Correspondence: Ali Odeh Hammoud Alidmat, Aqaba University College, Al-Balqa Applied University, Jordan. \\ E-mail: abuyazeed1977@yahoo.com
}

Received: September 3, 2019

Accepted: September 29, 2019 Online Published: November 1, 2019

doi:10.5539/ijel.v9n6p347

URL: https://doi.org/10.5539/ijel.v9n6p347

\begin{abstract}
This article focuses on the analysis of enactment of speech acts of offer and acceptance and their commissive effects in carrying out Sulha informal legal processes. Sulha is a method of resolving disputes used in the Middle East. These processes of Sulha are understood to operate within traditions set by communities that use the process in solving disputes. Just as formal legal processes, the success of a Sulha process is dependent on legal performative of a language used to carry out Sulha tribunals. This is based on the fact that it is through language that informal legal acts are enacted. The study is grounded on the Jordanian Bedouin dialect used in conducting Sulha tribunals whose translation equivalences are given in English. Data are collected through audio-recording which is backed up with note-taking. The audio-recorded data are then played back to identify the speech acts of offer and acceptance. The identified acts of offer and acceptance are then analyzed within the framework of Searle's (1979) classification of speech acts. In terms of methodology, the study adopts descriptive research design whereby the speech acts of offer and acceptance are described as they occur in the legal discourses used in the informal legal process, Sulha.
\end{abstract}

Keywords: acceptance, Bedouin, commissive, legal, offer, performative, Sulha

\section{Introduction}

The principle units of human communication are speech acts (Geurts, 2018). These speech acts, as noted by Geurts (2018), include promises, orders, vows, acceptances, offers and so on. The choice of the acts depends on the intent of the speaker, that is, what the speaker wants to enact using the speech acts (Austin, 1962; Searle, 1979). Worth noting also is that the speech acts have to be contextualized to achieve the speaker's intent (See Austin, 1962). Therefore, in an informal legal setting like Sulha, the discourses used to carry out the Sulha process will only be performative if the speaker and the hearer place themselves under obligation to do informal legal action contained in the Bedouin's traditions. This follows Fiorito's (2006) argument that a discourse only performs a legal act if placed in the legal domain. Given the fact that legal setting requires speech acts that are committal, it will be of necessity, therefore, to use commissive speech acts in performing legal actions (Fiorito, 2006; Tiersma, 1986). Some of the speech acts used in the formation of valid legal agreements, particularly in a conventional contract law, are offers, acceptances and considerations (Schane, 2012). The speech acts of offer and acceptance had earlier been attested by Tiersma (1986) in legal settings. According to Tiersma (1986), the speech act of offer and acceptance commit participants to future course of action. In this case, the speaker wants the world to be changed to fit his words which can be rejected or accepted by the hearer. Tiersma's argument on the committal legal act of offer and acceptance is grounded on formal legal setting. Legal settings, as observed by Kiguru (2014), are informed by explicit rules of evidence governing discourses used in these settings; power definition of court participants and goals set to be achieved through court processes. It will be important to attest the committal performance of the speech acts of offer and acceptance in an informal legal setting Sulha whose statute is defined by the conventions derived from Bedouin's traditions. This is what the current study is set to achieve.

\section{Background to the Study}

There exists an interrelationship between language and law (Danet, 1980; Kiguru, 2014; O'Barr, 1982; Supardi, 2016). This interrelationship explains the dependence of law enactment on language force (Danet, 1982). Studies that exist on the performance of language in enactment of law have been done in formal legal settings (Danet, 
1980; Fiorito, 2006; Kiguru, 2014). According to these studies by Danet (1980), Fiorito (2006), Kiguru (2014), O'Barr (1982) and Supardi (2016), discourses used in courtrooms attain their legal actions through well-defined frameworks forming legal systems that are captured in statutes. It is through these statutes, as reported by Kiguru (2014), that permissible and impermissible behaviors in the society are defined. In informal legal settings like Sulha, enactment of laws by languages may be reliant on conventions that are grounded on communities' traditions. This is based on Furr and Al-Serhan's (2008) argument that Sulha tribunals are governed by Bedouin's traditions, therefore, the operation of these tribunals must be within the traditions' framework. Given the fact that the Sulha tribunal is tradition's based, it would be interesting to find out how these traditions dictate performative of commissive speech acts: offer and acceptance during the Sulha process.

According to Fiorito (2006), language used in any legal system should adopt and discharge an obligations and commitments thus affecting social action. It is through the effect on social action by adopted and discharged obligations and commitments that court cases are solved to the satisfaction of court participants. Some of the most common speech acts used to enact commitment in courtrooms are offer and acceptance. Offer and acceptance, just as other commissive speech acts, have the force of committing the speaker to a particular proposal (Tiersma, 1986). Kiguru (2014) and Tiersma (1986) also insist that offer and acceptance as examples of commissive speech acts are not matters of expression or manifestation of intent. Rather, they are acts that commit the speaker to a particular course of conduct (Tiersma, 1986). Therefore, the speaker must intend to create in the hearer the perception that in saying the words, the speaker is committing himself to a particular proposal (Tiersma, 1986). The two speech acts, as observed by Tiersma (1986), achieve their legal performative by adhering to certain rules operationalised by formal legal setting. This, therefore, validates the observations made by Fiorito (2006), Kiguru (2014), O'Barr (1982) and Supardi (2016) that rules have to be put into consideration for a felicity in the discourses used in courtrooms. Tiersma's study on operation of offer and acceptance to achieve performative in a formal legal setting, opens a study gap of investigating how the two commissive speech acts in addition to other acts achieve their performative under different settings like Sulha tribunal which is an informal judicial system.

Of the two speech acts, offering is considered as the commonest act people use to make commitments (Allan, 1986; Vanderveken, 1990). This is a development from Bach and Harnish's (1979) subcategorization of commissive speech act into two: first involves obligating oneself to do something and second is about making offers by obligating to do something. A number of definitions on offer have been given by discourse analysts, for example, Fraser (1975) argues that in making an offer; a speaker proposes to place himself under an obligation to bring about the state of affairs expressed in the proposition. Hickey (1986), on the other hand, classifies offering among the set of acts that express commitments. These commitments are independent of the hearer and his/her reaction to it is irrelevant because the hearer may accept or refuse the offer (Hickey, 1986). The possible reactions of the hearer to the speaker's offer explains why sometimes the three speech acts offer, refusal and acceptance are analyzed as co-occurrent speech acts in discourses among interlocutors. The forms of these speech acts when used in legal setting, as explained by Santos (2004), are distinctive from common place offers, acceptance and refusal.

From Santos' (2004) point of view, legal discourse is classified as a sub-genre of professional discourse and is distinct from day to day human interaction. This distinctiveness according to Kiguru (2014) is attributed to number of factors such as explicit rules of evidence that govern verbal interaction in courtrooms; being goal oriented in which case there is emphasis on testimony that is sequential and that deals explicitly with cause and effect as well as identification of the agent to bear blame. The aforementioned factors are also known as felicity conditions which according to Fiorito (2006) enhance legal performative of discourses used in courts. The performative of the speech acts: offer and acceptance, as evidenced in Fiorito (2006); Kiguru (2014); Santos (2004) and Tiersma's (1986) works on language and law are limited on formal legal settings thus leaving a study gap in the operation of language and law in informal legal settings.

This study is, therefore, motivated by the fact that there is a scanty study on the performance of commitment by the two commissive speech acts of offer and acceptance in the discourses used in informal legal systems. To answer this study question, the study focuses on Sulha tribunal which is an informal legal judicial system. Related studies to the current study are the comparative investigation of Arabic and English legal texts in terms of structure and stylistic features (Bostanji, 2010). AlRabiah (2013) looks at linguistic features that make Arabic legal discourse to be special. AlRabiah is limited on written legal documents. Drawing from the two studies that could be accessed, no documented study has been done on the use of offer and acceptance in performing commitment in Sulha tribunal. This study is further justified by the fact that the speech acts common in making commitments in the Sulha tributes are the offer and acceptance. In fact, other acts built from offer and 
acceptance during the Sulha trials. These acts, as argued by Fiorito (2006) and Tiersma (1986), are meant for the creation of state of affairs as demanded by Bedouins' social conventions.

\section{The Sulha}

Sulha is defined as a non-state legal system that operates under specific patterns governed by social conventions set by the Bedouin community (Furr \& Al-Serhan, 2008). The term Bedouin emerged from the Arabic word "Bedu" which takes its root from the word "Badiya" meaning desert. Therefore, the literal translation of "Bedu", according to Layne (1994), is desert dweller. This community is characterized by pastoral nomadic life in which case it practices goat, camel as well as sheep husbandry. Through their search for pasture, the Bedouins identified Jordan as one of their permanent locations (Browning, 2013).

Culturally, the Bedouins adopt material simplicity of desert life - the material culture among the Bedouins is very simple. This simplicity, according to Khalid (2009), could be attributed to the raw materials from which traditional artifacts are made which are very limited and the unsettled nomadic life makes it difficult for the Bedouins to carry and produce plenty of material culture. Producers of these artifacts are women who are also responsible for making clothes from wool of sheep and goats. In terms of food, bread constitutes the most important food of the Bedouins prepared in the morning and evening by wives and daughters. As livestock keepers, milk products make up a large portion of the traditional Bedouin diet. Traditionally, the Bedouins practice informal education which was based on actual observation and participation in day-to-day life. Children are prepared for the life in their adulthood through the informal education (Khalid, 2009). Marriage among the Bedouins, as observed by Khalid (2009), is preferred between cousins and women tend to marry from age 16 and men at age 19. This marriage is strengthened by a traditional wedding which is done around the traditional coffee. This event is considered a joyful in which case a sheep is slaughtered. The event is scheduled for Fridays.

Another celebration that brings community together is the welcoming of the newborns as children are considered valuable among Bedouins. The Bedouins also have special ceremony called Maqam Al-Nabi Mousa believed to be the shrine of Prophet Moses. This ceremony is meant to help people heal from evil eye, evil spirits, jinn or madness (Khalid, 2009). The healing could also be through Quran. In the line of medicine, the community depended on herbal medicines. The much organised Bedouin system of life which is governed by the community's culture had resulted into formation of tribal law. Tribal law is a unique identity of Bedouins. This law undertakes the traditional and cultural principles of the Bedouin (Khalid, 2009). The law is unwritten; therefore, it depends upon verbal instructions handed down from father to son. The purpose of the system is for conflict resolution among the Bedouins at clan level. The Sulha system is used in resolving many different kinds of disputes including business, financial and consumer conflicts. The other disputes are murder offenses and family conflicts (Pely, 2009). Sharia law or formal legal systems, on the other hand, are used to adjudicate disputes between individual disputants, or between disputants and the state. As a justice restorative system, Sulha provides recognized and accepted platform for transition from revenge to forgiveness (Bajpai \& Verma, 1995; Lee, 2008; Liu \& Palermo, 2009; Mathew, 2000).

Trials in the Sulha, as in other informal judicial systems, are procedurally structured hence a uniformity in the way the Sulha tribunals are conducted (Hale, 1997). In fact, there are established customs strictly adhered to by participants in the Sulha tribunal. For example, according to the customs, a family has the right as well as commitment to protect its members (Abu Hassan, 1987; Al-Abbadi, 1982, 1986; Phillips, 2011; Stewart, 2005). Depending on how a case is handled in the Sulha, the case may cause danger to a whole community. For that matter, to revenge for a murder of a nearby member is very important; neglecting the revenge is considered dishonorable (Furr \& Al-Serhan, 2008). Success of Sulha proceedings, as observed by Stewart (2005), is also based on time factor. Being observant on time by the participants in Sulha proceedings ensures fast and smooth running of the proceedings. For instance, in case of a murder, the protector of the accused family for the murder must immediately go or send a group of notable persons to the aggrieved party's house with a Jaha to demand Atwa, that is, a truce or a period of time in which the aggrieved family promises not to get revenge until the Sulha council make ruling on the murder case.

The Sulha system operates in four phases: first phase involves visiting of plaintiff's family by the elders from the defendant's family. Second phase involve acknowledgement of conviction by respected groups of elders called Jaha. Third phase is about a demand for a truce known as Atwa by the Jaha in reward for protection to be offered. Fourth, Jaha visits the aggrieved party to convince them to accept Sulha (Suwaed, 2015). Sulha council is then conducted and an agreement reached followed by a feast and a handshake. As evident in the four phases, Sulha process is procedural and operates under systems defined by Bedouin tradition. These phases are characterized by unique use of language (Suwaed, 2015) hence the significance of analyzing speech acts of offer 
and acceptance and how the two acts are used to adopt and discharge commitment.

\section{Speech Act Theory}

Speech act theory as reported by Tiersma (1986) is a philosophical approach to language developed by Austin (1962) and Searle (1969). This theory attempts to explain how utterances of a speaker are related to surrounding world. Aitchison (1987), on the other hand, defines speech act as the overall approach by which philosophers and linguists have tried to classify the ways in which humans use language and so it is treated as parallel to actions which human perform (Aitchison, 1987). By echoing Austin (1962) and Searle's (1969) definition of speech act theory, Mey (1993) describes speech acts as an action happening in the world, that is, they bring a change in the existing state of affairs. Another definition has been given by Grundy (2000) who looks at the theory as the study of performative or the action accomplishing aspect of language use and in particular the illocutionary force associated with utterances. Grundy's definition is established on Austin's (1962) argument that all utterances could be classified as true or false statements but there are other utterances that cannot be classified as true or false yet uttering them constitutes part of or the doing of an action. Austin refers to those utterances attached to action doing as performatives adding that they contain performative verbs while those utterances that can be classified as true or false, he calls them constatives. He adds that performatives that contain performative verbs should be classified as explicit performatives while those that trigger an action yet they do not contain performative verbs should be called implicit performative. The current study applies both explicit and implicit performatives in analyzing the speech acts used in Sulha tribunals.

Speech acts consists of two other types of acts namely propositional act and illocutionary acts. As posited by Tiersma (1986), propositional acts refer and predicate. According to him the proposition such as "Sam smokes habitually" refers to Sam and it predicates that he smokes habitually. The proposition "Does Donna smokes habitually?" has the same predicate but a different referent: Donna. He concludes that because the proposition in these sentences is the same, each sentence performs the same propositional act. Nonetheless, the speaker's intent with respect to the proposition is different. This difference is attributed to difference in force each sentence impacts (Searle, 1969). The first sentence according to Tiersma asserts proposition while the second one asks question. Searle refers to these forces as illocutionary acts.

Also central to the speech act theory are five basic classes of speech acts distinguished in accordance with the taxonomic criteria proposed by Searle (1969). As observed by Searle, identification of speech acts into these five basic classes is based on the functions assigned to them. The five classes are representatives, directives, expressives, declaratives and commissives. The proposed study will employ the commissive speech acts. The illocutionary goal of commissive speech acts, according to Searle (1969) and Cohen's (1996), is attained by the speaker on condition that the speaker obliges to perform an action described by the propositional content of an utterance. Searle (1969) and Cohen (1996) add that commissives are not like impositives since commissives are only made performative if the speaker performs an action indicated by a discourse and the hearer becomes the benefactor from the result of this action. The commitments, as explained by Searle (1969), are made in terms of promises, offers, swears, guarantees, vows or threats. As an informal, judicial system, Sulha involves speech acts that are goal oriented. The main goal is usually conflict resolution through forgiveness and compensation (Furr \& Al-Serhan, 2008). The peace is achieved through exhaustive language use by the participants (Phillips, 2011). Because the Bedouin customary law demands commitments to the Bedouin traditions during the informal Sulha tribute (Furr \& Al-Serhan, 2008), commissive speeches would be expected to enhance performative of the language used during the process hence the choice of commissive speech act in this study.

Speech acts are understood to vary from one culture to another in different ways and these differences may introduce communication difficulties (Kasper, 1992). The culture-based variation in speech acts renders every study unique in the field of language use in both formal and legal settings. Drawing on cultural influences on operation of speech acts, it is worth examining how constructs of the acts are used to perform actions in Sulha tribunals which are established deeply in the Islamic law called Sharia law.

\section{Significance of the Study}

Sulha is meant to maintain relationships and the restore of harmony on all members of the Bedouin tribe (Al-Rahami, 2008; Phillips, 2011; Suwaed, 2015). For this to be achieved, language competence and performance must be considered (Chomsky, 1965). Performances of languages are enhanced by speech acts among which are commissive speech acts (Austin, 1962; Searle, 1969). It is hoped that the findings on the performance of offer and acceptance in the Sulha tribunal will improve the action of language used in the Sulha process. 


\section{Methodology}

The study adopts a descriptive research design in which case the forms of utterances are described as they are in the Sulha trials. The population of study was Bedouins living in Jordan speaking Arabic language and use the informal judicial system, Sulha in solving conflicts. The researcher focuses on 18 Sulha proceedings between January and June 2019. A total of 4 Sulha trials were randomly sampled from the 18 proceedings. The 18 Sulha proceedings took place in different days and those that happened in the same day differed in the sessions of the trials. The length of time each proceeding took varied from about 3-5 hours depending on the type of dispute handled and the weight of the case. These trials were audio-recorded using the gadget Hawaii 10 mate. The 4 trials were taken to be representative of the 18 proceedings given that the procedures and conventions that apply in the samples are also applied in all the other Sulha trials. The recorded data was played back for transcription. Audio-recording was backed up by notes the researcher was taking down during the Sulha proceedings. The data was then analysed within the framework of speech act theory.

\section{Findings and Discussion}

As discussed in section 3.0, trials in the Sulha are procedurally structured. In addition, they are governed by conventions which every participant has to adhere to. Based on their governorship by the Bedouin conventions which are tradition based and their procedural structure, Sulha trials are expected to exhibit homogeneity in the use of speech acts to enact law. An enactment of law, as argued by Fiorito (2006), requires committal speech acts of which offer and acceptance form part of. The two speech acts are presented in the following sub-sections with explanation of their committal impact in the Sulha trials.

\subsection{Offer}

The discourse function of offer is to commit a speaker to a given course of conduct (Tiersma, 1986). Tiersma's definition of the offer is grounded on Searle's (1969) analysis of this speech act. According to Searle (1969) for that matter, offer and acceptance are classified as commissive speech acts. This classification is based on the usual performance of commitments by offer and acceptance whenever the two acts are used in a conversation. Offer in this study is found to be used mostly by plaintiffs, defendants and guarantors in presence of a judge who presides over the case. Consider a guarantor's commitment to a verdict in the conversation in the insulting case in example (1).

Example 1: First Pleading

Judge: Is this your testimony?

Guarantor: Yes it is and you judge, is one of the best men here and we came to you as we know that you will judge fairly. ...This is my cousin and I shall be responsible for him rather than defendant and if said that he is a stealer, then that would be me, if I would say about him that then it would also mean me.

Judge: Go on with your evidence as you wish.

In the example (1) above, the guarantor commits to this case such that he is ready to offer facts about his cousin in line with the case in question. It is through the offer that the judge learns that guarantor is committed to proposals that he testifies by himself.

Performance of committal speech acts of offer during Sulha tribunals is facilitated by conventions that are grounded on Bedouin traditions. Some of these traditions include offender and his family's commitment to abide by whatever verdict the judge reaches through material offer. Consider the material offer in the second pleading of the insulting case in example (2).

\section{Example 2: Second Pleading}

Judge: Dear attendees. Now the matter is clarified to us, and I am not here for nothing, as I want to collect fees. I want two thousand Dinars from each one.

\section{The public: Fees?}

Judge: How would I judge without fees? Peace is upon the prophet, I will only take fees from the losing party and the remaining will be returned to you but after settling things down. Is there anything wrong with this?

Public: Not at all.

Judge: How much is this?

Public: Count them.

Judge: You count it. 
One of the publics: Two thousand.

Clerk: Each one shall sign the testimony.

Judge: I want my fees guarantor.

Guarantor: I don't have any money, I have 500 Dinars, and you either delay judgment or wait.

As noted in the conversation in the example (2) above is that commitment is adopted and discharged without necessarily using words of offer in the Bedouin hence an implicit performative. This performance is enhanced by felicity conditions within which Sulha tribunals operate, for instance, the commitment by the Sulha participants to accept outcome of the cases whether the outcome favors them or not. This is sometimes noted on the material offers they make at the end of a tribunal.

Performative of offer is also enhanced by a preparatory felicity condition namely status or authority of the participants. Consider the pleading in example (3).

Example 3: First Pleading

Defendant: Guarantor, do you accept that?

Guarantor: Yes, I do and I guarantee in my name and in the name of Bani Sakher tribe entirely.

Defendant: If I was judged to be innocent by the judge, what would guarantee returning me the fees that I paid to the judge?

Plaintiff: I assigned a guarantor for you to guarantee everything for you and upon you and I am responsible for that case and if I prove what I claim, I will be the losing party and this all will be guaranteed by the guarantor.

In example (3) above, the plaintiff and the defendant consider the judge as the highest authority hence their readiness for verdicts the judge will make whether favoring them or not. The readiness of the defendant and the plaintiff to own up to the verdict is conditioned by the authority conferred on the judge by Bedouin conventions which are driven from the community's tradition.

Conditions on offering can also be expressed in proposed bargain (propositional content). According to Tiersma (1986), propositional content specifies a promise of the speaker in exchange for a promise or future act of the hearer. In this case, an offer made by participants performs the role of committing the speaker not only to his promise but to accept also a specific promise or act in exchange (Tiersma, 1986). This is evidenced in Sulha trials as one way of satisfying both the plaintiff and the defendant. Consider the data in example (4).

Example 4: Second Pleading

Judge: I want a guarantor who would sign here. Who guarantees defendant for fees?

Defendant: He is my guarantor.

Judge: What do you say the guarantor?

Guarantor: Since he nominates me, then I won't disappoint him.

Judge: Guarantor you have one month.

Guarantor: Trading is limited by time.

Judge: Write instrument of maturity after one month from Abu Kharbeesh.

Guarantor: Hey Theeb, my (Abaya) would guarantee me (meaning my tribal position, my name or the name of my tribe will guarantee me.

As shown in the example (4) above, an offer made by the judge of allowing the defendant to choose his own guarantor commits the guarantor to act in exchange by accepting the one-month maturity period of the fees. This is evident in guarantor's readiness to guarantee the defendant the fees using his tribal position. Therefore, noted in this conversation in example (4) above is that a speech act can be used to enact another speech act. In this conversation, the speech act of offer has been used to make promise which is itself a commissive speech act.

\subsection{Acceptance}

Acceptance, as an act of offer, is used to commit the speaker to a proposed future course of action. This illocutionary act differs from assertions of a particular intent (Tiersma, 1986). Although it operates in much the same way as offer, acceptance, as argued by Tiersma (1986), there are diverse means by which a participant can accept an offer. In Sulha tribunals, acceptance is used to enact commitment thus developing trust among participants. As shown in example (3) above, in the process of assigning a defendant a guarantor, the defendant 
in the presence of the judge first asks for the guarantor's readiness to guarantee him. The guarantor shows his readiness through enactment of the speech act of acceptance by affirmatively saying "Yes I do accept".

The rules of the Sulha tribunal mandate the defendant to speak facts as he represents the entire tribe. As shown in example (3) above, guarantor accepts to grant the plaintiff his right if the plaintiff wins the case. Sulha tribunal puts this guarantor under obligation to accept charges in case he loses the case.

As seen in the act of offer in the Sulha tribunal, acceptance as an act also operates within particular felicity conditions of which religious beliefs form part of. This is illustrated in the pleading in example (5).

Example (5): Second Pleading

Judge: Praise the prophet, the solution is between you now, I will pronounce my judgment and not ashamed of anyone.

Defendant: I have only one thing to say, I accept it and Allah will reward me.

The conversation in the example (5) above is instigated by the exhaustion of all possible defenses the defendant could use to prove him innocent. Therefore, the judge having weighed all the complaints and defenses, is ready to make judgment on the case which the defendant is ready to accept with the belief that Allah will reward him for the step he has taken to accept the judgment.

\section{Conclusion}

It is established in this study that the acts of offer and acceptance enact force of commitment on the participants in the Sulha tribunals. These acts have uniformity in how they enact commitment based on the fact that the Sulha tribunals operate on the provisions by Bedouin's traditions. In fact, commissive acts are enhanced by felicity conditions ingrained in the social conventions set in the Sulha some of which include the Bedouins' mindset towards maintenance of peace; the Muslim religion and Sharia law which compel members to observe peace, justice and coexistence. Offer and acceptance are found to simultaneously operate in the process of making commitments by Sulha participants. In the case of simultaneous occurrence of the two acts, an offer is either accepted or rejected. This is evident in cases where an offer by the speaker is made performative on condition that the hearer accepts it or not. Other than felicity conditions that enhance enactment of acts of offer and acceptance in the Sulha tribunal, another crucial thing is that the speaker must have that intent to create in the hearer the illocutionary effect of the two forces by making the hearer to recognize the intention of the speaker when the tribunal is ongoing. It is also discovered in this study that informal legal effects of offer and acceptance emerge from functional physical act such as material offer.

\section{References}

Aitchison, I. (1987). Linguistics. Kent, Hodder and Stoughton Ltd.

Allan, K. (1986). Linguistic meaning. London: Routledge.

AlRabiah, M. R. (2013). Linguistic Features of Legal Language: A Contrastive Study of Saudi Arabia and Canada Labour Law. Published by European Centre for Research Training and Development UK.

Austin, J. L. (1962). How to Do Things with Words. Oxford: Clarendon Press.

Bostanji, A. J. (2010). Legal Translation in Saudi Arabia: A Contrastive Analysis of Linguistic Challenges Encountered by Practitioners. PhD Thesis. University of Western Sydney.

Chomsky, N. (1965). Aspects of the Theory of Syntax. Cambridge, MA: MIT Press. https://doi.org/10.21236/AD0616323

Cohen, A. D. (1996). Developing the ability to perform speech acts. Studies in Second Language Acquisition, 18, 253-267. https://doi.org/10.1017/S027226310001490X

Danet, B. (1980). Language in the legal process. Law and Society Review, 14(3), 446-564. https://doi.org/10.2307/3053192

Fiorito, L. (2006). On Performatives in Legal Discourse. Metalogicon Journal, XIX, 2.

Fraser, B. (1975). Hedged Performatives. In P. Cole \& J. L. Morgan (Eds.), Syntax and Semantics (Vol. 3, pp. 187-210). New York: Academic Press.

Furr, A., \& Al-Serhan, M. (2008). Tribal Customary Law in Jordan. South Carolina Journal of International Law and Business, 4(2), 1-19.

Grundy, P. (2000). Doing Pragmatics. Cambridge: Cambridge University Press. 
Hadher, H. A. (2016). Investigating the Use of the Two Speech Acts of Invitation and Offer among Iraqi EFL University Learners. PhD Thesis. University of Malaysia

Hickey, R. (1986). A Promise is a Promise: On Speech Acts of Commitment in English. Studia Angelica Posnaniesia, 18, 69-80.

Kasper, G. (1992). Pragmatic Transfer. Second Language Research, 8(3), 203-231. https://doi.org/10.1177/026765839200800303

Khoyi, A. M., \& Behnam, B. (2014). Discourse of Law: Analysis of Cooperative Principle and Speech Acts in Iranian Law Courts. Asian Journal of Education and e-Learning, 2(4), 312-322.

Kiguru, G. (2014). A Critical Discourse Analysis of Language Used in Selected Courts of Law in Kenya. Unpublished PhD Thesis. Kenyatta University. Kenya.

Mey, J. L. (1993). Pragmatics: An Introduction. Oxford: Blackwell. https://doi.org/10.1080/10350339309384418

O'Barr, W. M. (1982). Linguistic evidence: Language power and strategy in the courtroom. New York: Academic Press.

Phillips, F. P. (2011). Sulha: Traditional Arab Dispute Resolution. Business Conflict Management. By Peter Phillips.

Santos, M. (2004). A pragmalinguistic analysis of courtroom questions in a multilingual context. Retrieved December 13, 2016, from http://www.tesionline.it/consult/pdfpublicview.asp 8309/18309p.pdf

Searle, J. R. (1969). Speech Acts: An Essay in the Philosophy of Language. Cambridge, UK: Cambridge University Press. https://doi.org/10.1017/CBO9781139173438

Supardi, S. (2016). Language Power in Courtroom. The Use of Persuasive Features in Opening Statement. Indonesian Journal of Applied Linguistics, 6(1), 70-78. https://doi.org/10.17509/ijal.v6i1.2663

Suwaed, M. (2005). Historical Dictionary of the Bedouins. Rowman \& Littlefield Publishers.

Tiersma, P. M. (1986). The Language of Offer and Acceptance: Speech Acts and the Question of Intent. California Law Review, 74, 189-232. https://doi.org/10.2307/3480357

\section{Appendix A}

Original Arabic Version of the Examples Provided in the Text

$$
\begin{aligned}
& \text { المثال الأول: } \\
& \text { الحجة الأولى ( المر افعة الأولى): }
\end{aligned}
$$

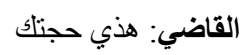

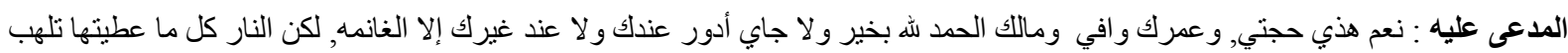

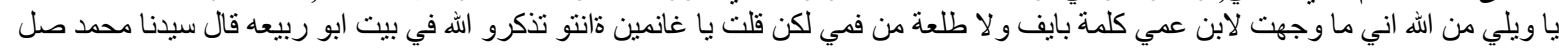

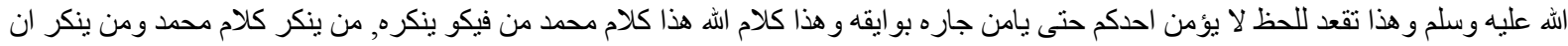

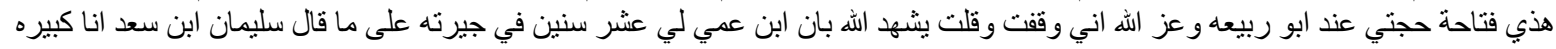

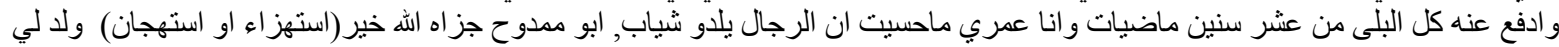

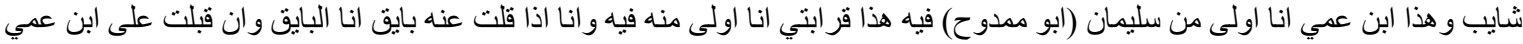

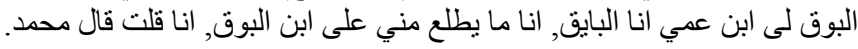
القاضي: تفضل احتج حجتلك الي انت ودكياها

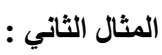

الحجة الثانية( المرافعة الثانية):

القاضي: يا غانمين الطرفين و الحضور. الانية بينت العين السالفه على ايش. وانا كمان مش قاد ببلاش انا ودي اترزق الله. ودي من كل واحد الفين دينار الفين ثثين من كل واحد الحن

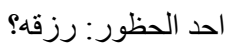

القاضي:( مستغربا) انا بسولف بيش طبعا بسولف بالرزقه. صلو على النبي اناودي اخذ بس رزقة المفلوج و الباقي اردهن عليكو لكن عقب ما تصفى الامور, في غلط في الكلام هذا يا غانمين

الجمهور: لا ابد الموري 


$$
\begin{aligned}
& \text { القاضي:(استلم مبلغ من ابو ممدوح, صاحب الدعوة) هذول قديش؟ }
\end{aligned}
$$

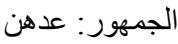

$$
\begin{aligned}
& \text { القاضي:( لاحد الموجودين) عدهن } \\
& \text { احد الحظور : كافي وو افي, الفين و افيات } \\
& \text { الكاتب: ضل كل واحد يوقع على الحجه } \\
& \text { القاضي: لا تستعجلو, الحجه عليها شهود و عليها توقيع ووقعو على الاول ومسجله }
\end{aligned}
$$

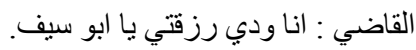

$$
\begin{aligned}
& \text { ابو سيف: انا در اهم ما معي. معي } 500 \text { ورقه صليت على النبي يا تأجلو حكمكم يا تصبرون }
\end{aligned}
$$

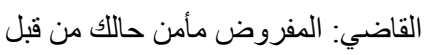

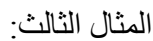

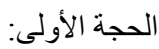

$$
\begin{aligned}
& \text { ابو سيف:(مخاطبا طر اد المسلط) عندك يا ابو اكرم؟ } \\
& \text { طر اد المسلط: عندي, عندي و عند كل بني صخر انا اكفل باسم بني صخر كلهج؟ } \\
& \text { ابو سيف: يوم اني اروح من عند القاضي ابيض وش الي يفك رزقتي؟ }
\end{aligned}
$$

ابو مددوح: يارجل انا حطيتلك كفيل و انت اليوم جابي في الي لي حسبتها عليك وانت مالك حجهاه, ان ثبتها عليك القول قولي ان ما ثبتها عليك انا الخسر ان بوجه طر اد اد المسلط اعطيك الرزقانه.

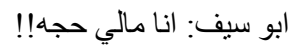

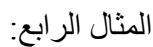

الحجة الثانية( المر افعة الثانية):

القاضي: عطني كفيل قبل اسولف انا(بمعنى قبل انطق بالحكم)

احد الحظور :الحق لساعه مو مبين( موجها كلامه لابو سيف بمعنى لاتخاف قد لا تكون المخطأ)

ابو سيف: و الله منا خايف من الحق

احد الحضور : اللي يخاف من من القاضي لا يجيه

ابو سيف: ابو خربيش كفيلي

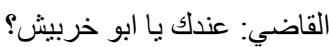

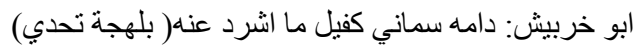

احد الحضور : في عرض ابو خربيش لما بييع ويشنري.

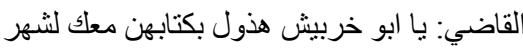

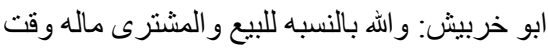

القاضي: (غاضبا) اسألكو بالله با غانمين اسألكو باله يا عارفين مو قلة ولة الرزقه فلج؟

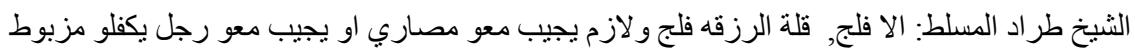

القاضي:( للكاتب) اكتب فيهن شهر عند ابو خربيش

ابو خربيش: يا ذيب يا ذيب عباتي انا تكفلني(تثديد على النام)

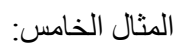

الحجة الثانية( المر افعة الثانية):

القاضي: صلي على النبي. هاضـا الساع الحل و الربط بيدك انا بعلمكو الكل بيسمع و لا انا خجلان من حدا

ابو سيف: ما عندي الا كلمه وحده. وش ما تقول راضي وحسبي الله ونعم الوكيل

\section{Copyrights}

Copyright for this article is retained by the author, with first publication rights granted to the journal.

This is an open-access article distributed under the terms and conditions of the Creative Commons Attribution license (http://creativecommons.org/licenses/by/4.0/). 